\title{
IAMJ
}

INTERNATIONAL

AYURVEDIC

MEDICAL JOURNAL

[d] $\subseteq$

\section{SLEEP - THE MOST NEGLECTED IMPULSE OF PRESENT AGE}

\author{
Veena J. Nair ${ }^{1}$, Athri S. S ${ }^{2}$, Jishnu $R^{3}$ \\ ${ }^{1}$ PGScholar, ${ }^{2,3}$ Associate Professor; \\ Dept. Samhita \& Siddhanta, Pankajakasturi Ayurvedic Medical College \& PG Centre, \\ Kattakada, Thiruvananthapuram, India
}

Corresponding Author: veenanairbams@gmail.com

\section{https://doi.org/ $10.46607 /$ iamj 11 p4052020}

(Published online: July 2020)

Open Access

(C) International Ayurvedic Medical Journal, India 2020

Article Received: 21/08/2020 - Peer Reviewed: 23/08/2020 - Accepted for Publication: 23/08/2020

Check for updates

\begin{abstract}
A good night sleep is required for wellbeing of every organism. Humans though considered as an intelligent among living beings, seldom understand the importance of sleep impulse and ignore it. This ignorance has paved way for many health issues. Impulses are generated for maintenance of body and must be managed at proper time. Sleep impulse is essential for various brain functions, production of various hormone like growth hormone, cognitive power, good immune response etc. Today in highly competitive world human have forgotten his body needs. Earlier handful of persons suffered from sleep disturbance unlike today, where sleep disturbance is very common factor almost in every household. This article is an attempt to pull in the importance of sleep impulse and the ill effects if not attended on time.
\end{abstract}

Keywords: sleep, impulse, health.

\section{INTRODUCTION}

The needs of body are expressed through different impulses. Ayurveda name it as Vegas. These impulses are generated for maintenance of body and must be managed at proper time. This will keep our body and mind healthy. Things which are impending to go out have to be expelled. If withheld will cause serious damage to body system. Impulses also must not be artificially manifested. Human body produce two types of vegas namely Adharaneeya which is not to be suppressed and Dharaneeya which is to be sup- 
pressed. Sleep is one such impulse which is to be attended at proper time. Sleep is a common impulse in almost all living organisms. But among living beings, human is the only creation who suppress the sleep impulse. Today's world seems to be ignorant about its consequences. Sleep impulse is either controlled or manifested at improper time. This way of living has paved way to various health issues. Human being is not nocturnal, but today's world seems to be available around the clock. Many factors like long working hours, globalization of business, load of academics, numerous amounts of television channels, night shift working etc. are the few causative factors for disturbed sleep.

\section{Aim and objective}

To discuss sleep impulse and its importance in Ayurvedic classical literature and modern texts.

\section{Materials and Methods}

This article is review of various Ayurvedic classical texts. Materials related to sleep and related topics have been collected from various Ayurvedic classical texts. Samhita used for this article were Caraka samhita, Sushruta Samhita, Asatanga Sangraha, Astanga hrdaya. Modern medical literature's as well as other various related information were collected from related website.

\section{Body impulse}

Every need is understood through expressions. For instance, an infant expresses his needs by crying. Similarly, our body expresses its needs through expressions named as impulse. Attending of these impulses is highly required for proper functioning of body and mind. Ayurveda classified Vegas basically into two namely as Adhareenya Vegas (not to be suppressed) and Dharaneeya Vegas (to be suppressed). Adhareenya Vegas are physically accelerated impulse and Dhareenya Vegas are psychologically accelerated impulse. Thirteen types of impulses are under

Adharaneeya Vegas namely flatus, defecation, micturition, sneezing, thirst, hunger, exertion breathing, yawning, tears, vomiting, seminal discharge, sleep. Suppression Vegas are under Dharaneeya Vegas which includes greed, worry, arrogance, etc. ${ }^{1}$ Sensible persons must have a control over these impulses. In short when these impulses are wrongly attended, it invites many health disorders.

Flatus are generally produced in bowel or stomach as gas formation, defecation is release of faeces from body and mutra is unwanted substances produced from cleaning blood by kidney, these must not be withheld rather thrown out. Sneezing is impulse, to unburden foreign matters collected in nose. In major, our body is made of water and its demand is fulfilled through impulse of thirst. Impulse to have food, is expressed through hunger. Doing strenuous activity, makes the body to produce impulse of exertional breathing. Less oxygen is satisfied by a yawn. Weeping helps to clear dust, smoke etc. from eyes. Vomiting throws out unwanted substances. Seminal discharge is required for reproduction. Sleep is one such impulse which is required for development of mind and has been considered one of supporting pillar.

\section{Sleep impulse}

Sleep: Sleep is normally recurring process of mind and body, with reduced interactions with the surroundings. In simple words, sleep is a state of rest which prepares to face the life next day.

A man gets sleep, when the mind is exhausted and sense organs gets detached from its objects ${ }^{2}$. Sushruta Acharya stated that proper sleep at proper time will make a person gain strength, peaceful mind, virility, will not suffer from any disease, body will neither be skinny nor stout and thus live for hundred years ${ }^{3}$. In Harita Samhita, different state of sleep irregularities is untimely sleep, excessive sleep even when slept on right time and lack of sleep. A perfect sleep will provide happiness, nourishment, strength, virility and clear understanding. Improper sleep will cause delusion, headache, oedma etc. Accepted time of sleep is during night. So generally, day sleep is to be avoided. But Ayurveda permits day sleep for individuals in certain conditions like, who have got emaciated due to constant reading, singing, for aged, children, carry heavy loads, during indigestion, dysnoea, who consumes excess alcohol etc. Among different seasons, only during summers day sleep is allowed due to short nights ${ }^{4}$. Getting sleep at proper time is one of the signs of being a healthy human. 
Modern research about sleep commenced with a book release by French psychologist Henri Pieron. Hypothalamus in brain initiates sleep. There are two stages of sleep namely rapid eye movement (REM) and nonrapid eye movement (non-REM). Sleep is essential for various brain functions, production of various hormone like growth hormone, cognitive power, good immune response etc. Various creative solutions emerge through sleep. It is interesting to know that some solutions to problems get solved through sleep. Formulation of Benzene structure by Friedrich Kekule happened through sleep. In short, sleep helps to make us feel better and highly essential for normal functions of body and mind.

\section{Factors affecting sleep}

Most people worry if they spend a little time in sleep. As it is believed that sleeping is considered as more or less an impulse which is to be controlled. Age, nature of job, diminution of tissue, any diseases, increase of Vata and Pitta are some cause mentioned for disapproval of sleep impulse. Human is only creation which do not attend the sleep impulse seriously.

Thinking a lot, anger, physical strain, uncomfortable bed, improper purgation, nasal administration, emesis, bloodletting, fear, smoking, etc., cause sleep disturbance. ${ }^{5}$ Once sleep is suppressed there will be frequent yawing, agony all over body ,heaviness in head and eyes as well as delusion. ${ }^{6}$ Sleeping at inappropriate time causes weariness of mind, injury to body, depletion of tissues, headache, weakness of digestive functions etc. ${ }^{7}$ Sleep is also influenced by nature of foods and drinks. Sour, bitter taste produce moderate to disturbed sleep. Sweet, easily digestible foods etc. promote good sleep. Long working hours, night shift work, globalization of work, watching large number of television channels etc. are some of the causes which disturbs the normal sleep time. Night shift work will adversely affect health causing fatigue, poor performance, digestive disturbances. To add on, its increased risk of accidents as there will be impaired cognition. Cardiovascular diseases, diabetes, cancer anticipate especially in night shift workers as well as others who stay awake late nights. ${ }^{8}$ Due to globalization of work, many have to jump into multiple time zones thereby inviting health disorders like fatigue, gastrointestinal problems, impaired cognition etc. Travelling among multiple time zones causes sleep disorder and this condition is known as jet lag. Sports performance is also affected due to jet lag. Studies suggest that breast cancer is more evident in night shift working woman as well as flight attendants etc. Only recently WHO recognized shift work as one among the carcinogens. Bright light from screen devices like television, smart phones, laptop etc. add on the list of causes of sleep disturbance. Young children spend their valuable childhood in front of these screens. This affects their mental growth. Sleep is associated with circadian rhythm. Blue light from these screens affect the circadian clock as it delays release of melatonin. Circadian clock is sleep wake cycle. Growth hormone is sleep dependent. Children are subjected to great stress with loads of academic works which makes them stay awake late nights. Less of night sleep can be compensated by sleeping during day.

But in reality, it cannot be utilized as they will be chasing class hours. Sleep deprivation in such children causes classroom sleep, low grades, poor mind and behavior. Drugs and alcohol add on the reason for sleep disturbance. Another major cause is usage of caffeine. Caffeine are abundant in tea, coffee, energy drinks, chocolate etc. so it is advised to stop caffeine usage five hours before for sleeping well. Factors affecting sleep add on to the list with time.

\section{DISCUSSION}

Sleep is such an impulse if not attended on time will affect memory, concentration, metabolism, hormone levels, cause poor concentration, low immune power, even weight gain. Abnormal sleep pattern occur along with poor mental health was stated by one of the founders of modern psychiatry Emil Kraepelin. Lack of proper understanding of the sleep is the main reason for its negligence. It is high time to understand the importance of sleep and attend the impulse religiously.

Some steps can be adopted to prevent sleep disturbances, like avoid going late to sleep, no usage of 
screen based device in bedroom, avoiding caffeine during evenings, avoiding large amount of liquids late evening, right planning of travel to prevent jet lag etc. When we keep a correct time for sleep, our body will automatically produce impulse on time. Screen based device like mobile, computer, television etc. emits blue light which prevents sleep. Caffeine increases body temperature, blood pressure, heart rate, acid reflux, caffeine induced anxiety and sleep disorders. Without proper planning of travel through multiple time zones, causes fatigue, insomnia, gastrointestinal disturbances etc. So, an intelligent plan to escape the jet lag need to be adopted.

When sleep deprivation occurs, measures to enhance sleep are to be adopted like, daily bathing, keeping surrounding and body clean, comfortable bed, avoid day sleep and going late for sleep, proper ventilation in the bedroom, milk of buffalo etc. Factors affecting sleep impulse is growing rapidly. Today in highly competitive world human have forgotten his body needs. They work hard to earn more and provide comfort to oneself and family. But to utilize these comforts a healthy body is required. Elements which causes hurdles must be understood and banished out. In this way there will be a proper sense in hard work for earning. It is often seen the impulse of hunger get satisfied more than sleep. We keep awake with snacks to watch a live match or film during night. There are more distractions for sleep so one must get rid of all these and sleep on time. Sleep if attended at wrong time will reduce sleep duration and its quality. It also affects hormone levels and metabolism which paves way for diabetes, obesity etc. A good sleep at proper time will boost the development of calm mind. Thus, one should consider the impulse of sleep as of utmost importance and attend it on time.

\section{CONCLUSION}

Sleep impulse is indeed a sub pillar of body beside food and sexual activity. For a calm stable mind, sleep is crucial. A calm mind will give right instructions to the body ultimately providing health. So, it is duty of every human to give importance to the impulse of sleep and to attend it on time.

\section{REFERENCES}

1. Prof. K. R. Srikanthamurthy, Translator, Astanga Hrdaya, Sutra, Ch4. Ver24.5th Edition, Varanasi, Chowkhamba Krishnadas Academy, 2007, Pg.49

2. Prof. Priyavrat Sharma, Translator, Caraka Samhita, Sutra, Ch21.Ver35.7th Edition, Varanasi, Chaukhambha Orientalia, 2001, Pg147

3. Prof. K. R. Srikanthamurthy, Translator, Sushruta Samhita, Sharira, Ch4. Ver40.3rd Edition, Varanasi, Chaukhamba Orientalia,2007, Pg.65

4. Prof. K. R. Srikanthamurthy, Translator, Astanga Hrdaya, Sutra, Ch4. Ver24.5th Edition, Varanasi, Chowkhamba Krishnadas Academy, 2007, Pg.49

5. Prof. Priyavrat Sharma, Translator, Caraka Samhita, Sutra, Ch21.Ver57. 7th Edition, Varanasi, Chaukhambha Orientalia, 2001, Pg149

6. Prof. K. R. Srikanthamurthy, Translator, Astanga Hrdaya, Sutra, Ch4. Ver12.5th Edition, Varanasi, Chowkhamba Krishnadas Academy, 2007, Pg.47

7. Prof. K. R. Srikanthamurthy, Translator, Astanga Hrdaya, Sutra, Ch7. Ver61.5th Edition, Varanasi, Chowkhamba Krishnadas Academy, 2007, Pg.120

8. Steven W. Lockley And Russell G. Foster, Sleep-A Very Short Introduction, Ch9. Oxford, Oxford University Press, 2012, Pg129.

\section{Source of Support: Nil \\ Conflict of Interest: None Declared}

How to cite this URL: Veena J. Nair et al: Sleep - The Most Neglected Impulse Of Present Age. International Ayurvedic Medical Journal \{online\} 2020 \{cited July, 2020\} Available from: http://www.iamj.in/posts/images/upload/2433 2436.pdf 